\title{
A Rare Case of 10-Year-Old Glomus Tumour with Excellent Response to Surgical Excision
}

\author{
Amtul Shaheen Banu ${ }^{1}$, Nayeem Sadath Haneef ${ }^{2}$, Nikhat ${ }^{3}$ \\ ${ }^{1}$ Department of Dermatology, Venereology and Leprosy, Deccan College of Medical Sciences, \\ Hyderabad, Telangana, India. ${ }^{2}$ Department of Dermatology, Venereology and Leprosy, Deccan \\ College of Medical Sciences, Hyderabad, Telangana, India. ${ }^{3}$ Department of Dermatology, \\ Venereology and Leprosy, Deccan College of Medical Sciences, Hyderabad, Telangana, India.
}

\section{INTRODUCTION}

Glomus body is an arteriovenous anastomosis located mostly in the finger nailbed and has a role in thermoregulation. Glomus tumour is a rare benign hamartoma, comprising of vascular spaces (the Sucquet-Hoyer canal) internally lined by endothelium and externally surrounded by glomus cells, arising from the glomus body at arterial end. 1,2 Wood first reported it in 1812.1

Most of the glomus tumours are small, benign neoplasia located in the dermis and subcutaneous tissue of the extremities. ${ }^{3}$ They can vary in number from being solitary most often or multiple in few cases. They can develop in any part of the body. They account for $1-5 \%$ of all hand tumours. They are most commonly seen in middle age women. One such rare case of glomus tumour of 10 years duration is reported here.

\section{PRESENTATION OF CASE}

A 38-year-old housewife presented with history of spontaneous shooting type of pain over the tip of right middle finger especially under the nail plate, since 10 years. Pain increased in intensity especially during the night. There was history of aggravation with pressure and cold exposure. There was no history of associated colour changes in involved finger. There was partial relief from pain with analgesics. There was no history of itching around the involved digit. There was no history of other fingers involvement. There was no history of similar complaints in family members. Examination revealed an approximately $8 \mathrm{~mm}$ size tender, slightly bulbous swelling seen appearing to be underneath the nail plate of right middle finger (Fig. 1a, 1b). Love's pin test was positive whereby gentle pressure with pinhead elicited excruciating pain in the involved finger. Radiological examination by X -Ray showed erosion of volar cortex of distal phalanx of right middle finger (Fig. 2a). MRI showed STIR T2 lobulated hyperintense area over the dorsal aspect causing erosion of distal phalanx (about $10 \times 9 \mathrm{~mm}$ size) (Fig. 2b) suggestive of glomus tumour. Hence, excisional biopsy was done.
Corresponding Author: Dr. Amtul Shaheen Banu, Flat No. 205,

Deccan Residency Apartments, Akbarbagh X Road, Malakpet, Hyderabad-500036, Telangana, India. E-mail: amtulshaheen7@gmail.com

DOI: $10.14260 / \mathrm{jemds} / 2020 / 288$

Financial or Other Competing Interests: None.

How to Cite This Article:

Banu AS, Haneef NS, Nikhat. A rare case of 10-year-old glomus tumour with excellent response to surgical excision. J. Evolution Med. Dent. Sci. 2020;9(15):1322-1324, DOI: $10.14260 /$ jemds/2020/288

Submission 10-02-2020,

Peer Review 22-03-2020,

Acceptance 28-03-2020,

Published 13-04-2020.
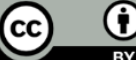
Histopathological examination showed proliferating reticular meshwork, trabeculae nests of polygonal to spindle glomus cells with round hyperchromatic nuclei, moderate eosinophilic cytoplasm with intervening cribriform pattern of small enlarged vascular channels which are classical features of glomus tumour (Fig. 3a, 3b). There was excellent pain relief after excision (Fig. 4a, 4b).
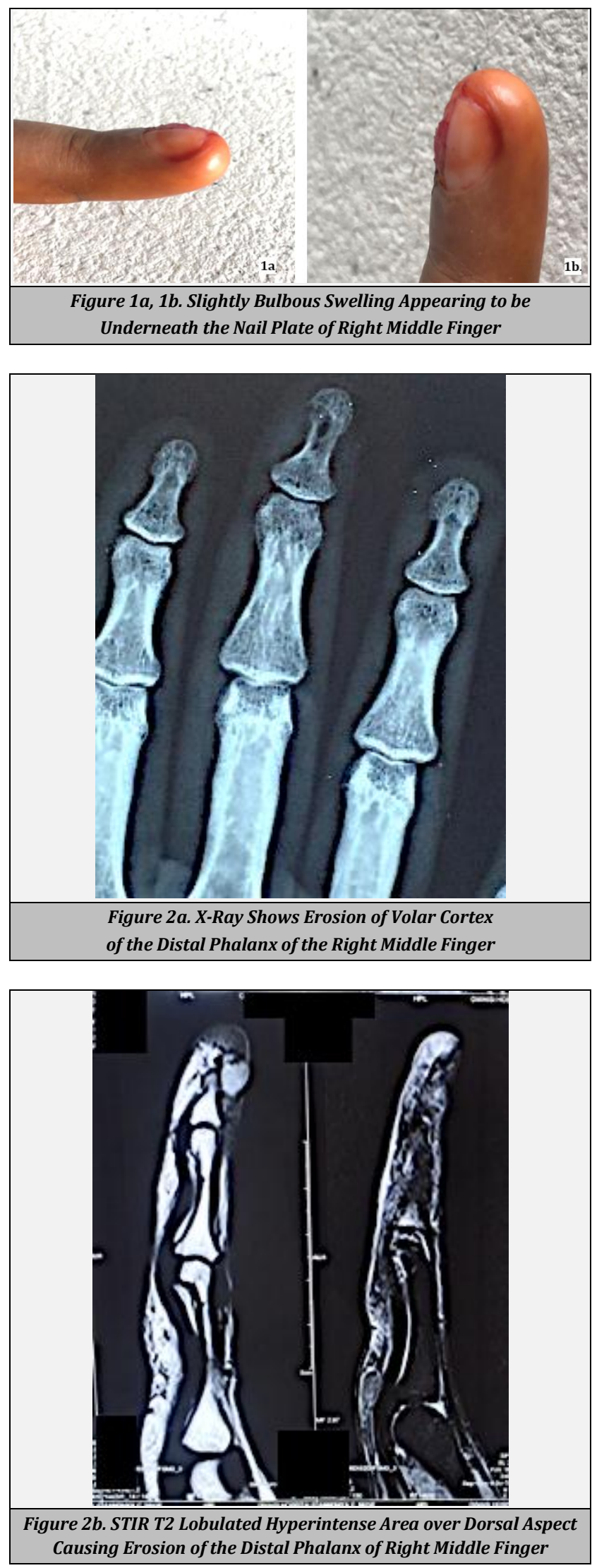

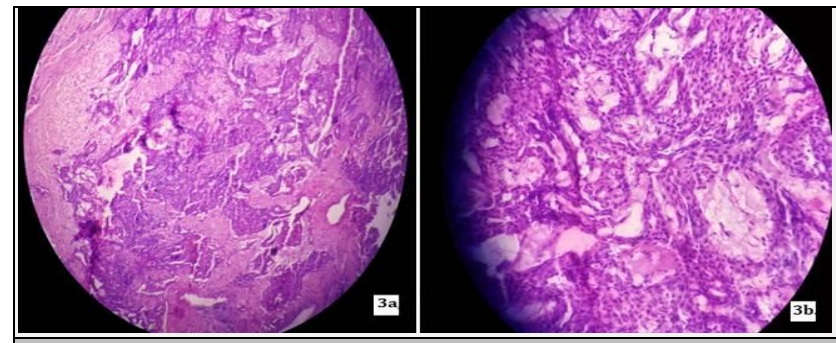

Figure 3a, 3b. Histopathologically Shows Proliferating Reticular Meshwork, Trabeculae Nests of Polygonal to Spindle Glomus Cells with Round Hyperchromatic Nuclei, Moderate Eosinophilic Cytoplasm with Intervening Cribriform Pattern of Small Enlarged Vascular Channels; Classical Features of Glomus Tumour. (H\&E:10X/40X).

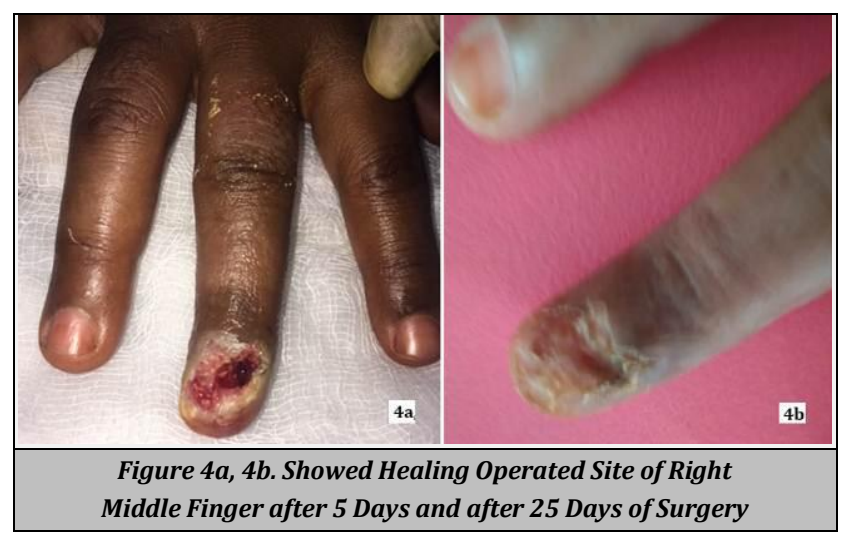

DISCUSSION

Glomus tumours are very painful benign tumours. Familial cases having autosomal dominant inheritance has been described suggesting role of genetic factors. ${ }^{4}$ Glomulin gene at chromosome 1p21-22 have been identified in multiple inherited glomangiomas. ${ }^{5}$ Here in our case there was no history of similar complaints in family members.

They most commonly seen in $4^{\text {th }}$ or $5^{\text {th }}$ decade of life but can occur at birth, infancy or childhood rarely. In children multiple tumours are 10 times more common than in adults. ${ }^{5}$ Here in our case the patient was 38 years old.

Clinical presentation of solitary glomus tumour is characterized by a reddish-purple swelling associated with triad of paroxysmal pain, tenderness, and cold-sensitivity as have observed in our case. The lesion is usually located on the extremities, especially the nail bed, as seen in our patient, but may occur on other parts of the body such as head, neck, penis or mucosa. Glomangiomas are autosomal-dominantly inherited multiple glomus tumours which have appearance of a haemangioma and are less painful then the solitary glomus tumour. Extracutaneous involvement such as intra-oral that does not contain glomus cells has been reported. ${ }^{6}$ Atypical features of glomus tumours include deeper infiltrative growth in soft tissues with relatively great size, extent or visceral involvement and multi-centric in origin with occasionally malignant transformation. 7,8

Clinical bedside test described in detecting solitary glomus tumour in nailbed are -Love's test and Hildreth's test. Applying pressure to a particular site using tip of pen/ pencil/ pointed object will elicit pain sensation at that site is described as Love's test. It has a sensitivity of $100 \%$. Whereas Hildreth's 
test consist of elevation of affected limb and application of cuff of sphygmomanometer on the proximal arm followed by inflating the cuff, the test is positive if pain subsides. Love's test was positive in our case along with cold-sensitivity. ${ }^{9}$

Histopathologically, glomus tumour is characterised by well circumscribed, smooth lobulated tumour in the dermis with proliferating reticular meshwork, trabeculae nests of polygonal to spindle glomus cells with round hyperchromatic nuclei, moderate eosinophilic cytoplasm with intervening cribriform pattern of small enlarged vascular channels. These features were characteristically seen in our case as well. Solitary painful lesions are cellular with more glomus cells than the multiple, larger, less painful lesions which have more dilated vascular spaces.

Glomus tumours can be classified as solid glomus tumour, glomangiomas, and glomangiomyomas. On electron microscopy glomus cells are seen as horizontally sectioned smooth muscle cells and not associated with nerve fibres. ${ }^{10}$ Tumour cells are positive for actin of smooth muscle and negative for desmin. CD34 positivity may be seen. ${ }^{11}$ Glomangiosarcoma are very rare malignant glomus tumour.

Routine investigation studies have little to no role in diagnosis of glomus tumour. Radiological examination such as $\mathrm{x}$ ray and standard magnetic resonance imaging (MRI) has been used to detect glomus tumours. With high-resolution MRI, diagnostic characteristics of the tumour are more accurately made out as seen in our case. ${ }^{12}$

Solitary glomus tumour is to be differentiated from various painful tumours including leiomyoma and eccrine spiradenoma which is made on the bases of histological examination. Blue rubber bleb naevus and cavernous haemangioma are difficult to differentiate glomangiomas. ${ }^{13}$ Other painful tumours of skin include Neuroma, Dermatofibroma, Tufted angioma, Angiolipoma, Neurilemmoma, Endometrioma and Granular cell tumour. (BLEND TAN EGG). ${ }^{14}$

There is no satisfactory topical treatment option for glomus tumour. Surgical excision is the treatment of choice. Recurrence occurs mainly if there is incomplete excision of tumour and if deep infiltrative lesions are present. Sclerotherapy, $\mathrm{CO}_{2}$ laser, pulse dye laser have been tried which are effective in preventing recurrences. ${ }^{15}$

\section{CONCLUSIONS}

The patient reported by us had undiagnosed glomus tumour since 10 years. High index of suspicion on clinical examination aided by MRI clinched the diagnosis. Surgical excision led to excellent pain relief.

\section{REFERENCES}

[1] Dawber RP, Baran R. Disorders of nails. In: Champion RH, Burton JL, Ebling FJG, eds. Rook/Wilkinson/Ebling Textbook of Dermatology. $5^{\text {th }}$ edn. Oxford: Blackwell Science Publishing 1992; p. 2497-532.

[2] Heys SD, Brittenden J, Atkinson P, et al. Glomus tumour: an analysis of 43 patients and review of the literature. $\mathrm{Br}$ J Surg 1992; 79(4):345-7.

[3] Enzinger FM, Weiss SW. Soft tissue tumors. $2^{\text {nd }}$ edn. St. Louis: C. V. Mosby 1988; p. 422-32.

[4] Carroll RE, Berman AT. Glomus tumors of the hand: review of the literature and report on twenty-eight cases. J Bone Joint Surg Am 1972; 54(4):691-703.

[5] Boon LM, Brouillard P, Irrthum A, et al. A gene for inherited cutaneous venous anomalies ('Glomangiomas') localizes to chromosome 1p21-22. Am J Hum Genet 1999; 65(1):125-33.

[6] Kohout E, Stout AP. The glomus tumor in children. Cancer 1961; 14(3):555-66.

[7] Geraghty JM, Thomas RW, Robertson JM, et al. Glomus tumour of the palate: case report and review of the literature. Br J Oral Maxillofac Surg 1992; 30(6):398-400.

[8] Gould EW, Manivel JC, Albores-Saavedra J, et al. Locally infiltrative glomus tumors and glomangiosarcoma: a clinical, ultra-structural and immunohistochemical study. Cancer 1990; 65(2):310-8.

[9] Murthy PS, Rajagopal R, Kar PK, et al. Two cases of subungual glomus tumor. Indian J Dermatol Venereol Leprol 2006; 72(1):47-9.

[10] Venkatachalam MA, Greally JG. Fine structure of glomus tumor: similarity of glomus cells to smooth muscle. Cancer 1969; 23(5):1176-84.

[11] Mentzel T, Hugel H, Kutzner H. CD34-positive glomus tumor: clinicopathologic and immunohistochemical analysis of six cases with myxoid stromal changes. J Cutan Pathol 2002; 29(7):421-5.

[12] Van Ruyssevelt CEA, Vranckx P. Subungual glomus tumour: emphasis on MR angiography. Am J Roentgenol 2004; 182(1):263-4.

[13] De Sablet M, Mascaro JM. Multiple glomus tumors and blue rubber bleb nevus. Ann Dermatol Syphiligr (Paris) 1967; 94(1):35-46.

[14] Bhat MR, George AA, Jayaraman J. Painful tumors of the skin- from England to lend an egg to blend tan egg. Indian J Dermatol Venereol Leprol 2019; 85(2):231-4.

[15] Lee SH, Roh MR, Chung KY. Subungual glomus tumours: surgical approach and outcome based on tumour location. Dermatol Surg 2013; 39(7):1017-22. 